技術報告

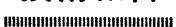

\title{
鋳片最終凝固位置近傍の電磁攪拌効果
}

\author{
水上 秀昭*.小松 政美*.北川 融*.川上 公成*2
}

\section{Effect of Electromagnetic Stirring at the Final Stage of Solidification of Continuously Cast Strand}

\author{
Hideaki Mrzukami, Masami Komatsu, Toru Kitagawa, and Kiminari Kawakami
}

\section{Synopsis :}

It is commonly observed that severe V-channel segregates are associated with the equiaxed zone in the central region of a strand. This type of segregation may deteriorate the product qualities especially for sour gas service. The modification of $\mathrm{V}$-segregates is found to be attained by electromagnetic stirring at the final stage of solidification. The laboratory scale stirring experiments have been carried out in order to eliminate $\mathrm{V}$-segregation and the following results have been obtained.

1) V-segregation streaks can be eliminated by linear or rotary type stirrer at the final stage of solidification.

2) The upward flow of molten steel at the solidification front which may prevent the inter-dendritic liquid flow toward the bottom is effective.

3) In the case of stirring by rotary type stirrer, adequate amount of fine equiaxed crystals is necessary. Alternating stirring at the final stage of solidification may prevent coagulation of equiaxed crystals and modify the packing of them.

4) It was found that only weak stirring is enough.

5) It is important to time the stirring to the progress of solidification. Optimum stirring period should be aimed at right after the precipitation of crystals, fraction of solid equals to 0.1 at the center of a strand.

\section{1. 緒 \\ 言}

連続鋳造に打いて，鋳片中心部の等軸晶を増加させ， 内質の向上を計るため，鋳型内や二次冷却帯上部に打け る未凝固溶鋼の電磁攪拌技術が適用されている(1) 4).

一般に鋳型内や二次冷却帯に打ける攪拌により，鋳片 中心部の等軸晶は増加し中心偏析, センターポロシティ は大幅に改善される.しかしながら, 最終凝固部に十分 な量の等軸晶領域を生成せしめると，逆に凝固の最終段 階での収縮に伴う下方への濃化溶鋼の吸引現象により $\mathrm{V}$ 状のストリーク（V偏析）が形成され，これが高級鋼製 造上の困難な問題となり連鋳適用鋼種の拡大を阻害して いる.

最終凝固位置近傍で等軸晶領域を攪拌することは等軸 晶の充媜に効果があり $\mathrm{V}$ 偏析の生成防止にもつながると 思われ，最終凝固部の等軸晶領域を攪找する電磁攪找方 法について実験室的検討を行つたので報告する。

\section{2. 実 験 方 法}

最終凝固部に十分な量の等軸晶を有するブルームまた
はビレットの軸心近傍の凝固をシミュレートするため, 真空溶解した $250 \mathrm{~kg}$ の溶鋼を $150 \mathrm{~mm}$ ，高さ $1 \mathrm{~m}$ の 耐火物製の鋳型に鋳造し，中心部を等軸晶凝固させた. 実験に供した溶鋼の組成を Table 1 に，および実験装 置の概略を Fig. 1 に示した。

粯汼方法の検討を行らため，Table 2 に仕様を示した リニア型あるいは旋回型の攪汼コイルを鋳型の高さ方向 の中心に設置した・リニア型靦抖コイルを用いた摫拌奏 験では 1 対のコイルを鋳型の 4 面のうちの 2 面に相対し て設置している。この場合，コイルを設置してある面の 凝固界面に上昇流を与えた場合には，他の 2 面には下降 流が発生することを水銀モデル実験により確認してい る.

Table 3，4 に示す攪拌条件の下で実験を行い，鋳片 のマクロ組織，成分偏析等を調查した. Table 中の $D_{\mathrm{s}}$ は固相率 $\left(f_{\mathrm{s}}\right)$ が 0.3 に相当する凝固界面の覺汼時に拉 ける表層からの距離である. $D_{\mathrm{s}}=50 \mathrm{~mm}$ は鋼塊中心で 固相が晶出し始める時期に，また $D_{\mathrm{s}}=35 \mathrm{~mm}$ は少なく とも $40 \mathrm{~mm}$ の完全液相領域が中心部に存在する時期に 相当することを予備実験により確認している．また最終

昭和 57 年 4 月本会講演大会にて発表 昭和 58 年 6 月 29 日受付 (Received June，29，1983)

* 日本鋼管 (株) 技術研究所 (Technical Research Center, Nippon Kokan K. K., 1-1 Minamiwatarida-cho Kawasaki-ku 210)

*2 日本鋼管 (株) 技術研究所 工博 (Technical Research Center, Nippon Kokan K. K.) 
Table 1. Chemical composition of steel.

\begin{tabular}{cccccc}
\hline$\% \mathrm{C}$ & $\% \mathrm{Si}$ & $\% \mathrm{Mn}$ & $\% \mathrm{P}$ & $\% \mathrm{~S}$ & sol Al\% \\
\hline 0.15 & 0.20 & 0.70 & 0.015 & 0.015 & 0.030 \\
0.45 & 0.20 & 1.05 & 0.015 & 0.015 & 0.030 \\
\hline
\end{tabular}

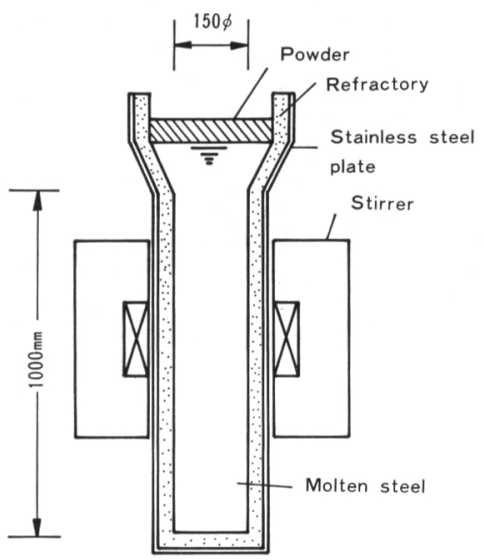

Fig. 1. Schematic diagram of experimental apparatus.

Table 2. Specifications of stirrer.

\begin{tabular}{lll}
\hline \multicolumn{1}{c}{ Type } & \multicolumn{1}{c}{ Linear } & \multicolumn{1}{c}{ Rotary } \\
\hline No. of phases & 3 & 3 \\
No. of poles & 2 & 2 \\
Frequency & $50 \mathrm{~Hz}$ & $50 \mathrm{~Hz}$ \\
Electric current & $\mathrm{Max} .800 \mathrm{~A}$ & $\mathrm{Max} .1700 \mathrm{~A}$ \\
Capacity & $100 \mathrm{kVA}$ & $150 \mathrm{kVA}$ \\
Core size & $165 \mathrm{~mm} \times 575 \mathrm{~mm}$ & $300 \phi, 150 \mathrm{mmH}$ \\
\hline
\end{tabular}

Table 3. Stirring conditions by linear type stirrer.

\begin{tabular}{|c|c|c|c|}
\hline Condition & $\begin{array}{r}\text { Stirring } \\
\text { direction }\end{array}$ & $\begin{array}{l}\text { Stirring } \\
\text { intensity }\end{array}$ & Stirring pattern \\
\hline A & \multicolumn{3}{|c|}{ without stirring } \\
\hline B & $\uparrow$ & $700 \mathrm{~A} \%$ & $1 \mathrm{~min}$ continuous \\
\hline C & $\uparrow$ & $700 \mathrm{~A}$ & at $D_{\mathrm{s}}=50 \mathrm{~mm}$ \\
\hline D & $\uparrow$ & $400 \mathrm{~A}$ & $10 \mathrm{~s}$ interval \\
\hline $\mathrm{F}$ & $\downarrow$ & $700 \mathrm{~A}$ & at $D_{\mathrm{s}}=50 \mathrm{~mm}$ \\
\hline $\mathrm{E}$ & $\uparrow$ & $700 \mathrm{~A}$ & $\begin{array}{l}1 \mathrm{~min} \text { continuous } \\
\text { at } D_{\mathrm{s}}=35 \mathrm{~mm}\end{array}$ \\
\hline
\end{tabular}

Table 4. Stirring conditions by rotary type stirrer.

\begin{tabular}{cl}
\hline $\begin{array}{c}\text { Stirring } \\
\text { intensity }\end{array}$ & $U_{\mathrm{Fe}}=10-20 \mathrm{~cm} / \mathrm{s}$ at final stage of solidification \\
\hline $\begin{array}{c}\text { Stirring } \\
\text { timing }\end{array}$ & $\begin{array}{l}\text { first stage of solidification } \\
\text { (crystal multiplication) } \\
\text { final stage of solidification, } D_{\mathrm{s}}=50 \mathrm{~mm} \text { and } 35 \mathrm{~mm} \\
\text { (packing of equi-axed crystals) }\end{array}$ \\
\hline $\begin{array}{l}\text { Stirring } \\
\text { pattern }\end{array}$ & $\begin{array}{l}\text { continuous } \\
\text { alternating }\end{array}$ \\
\hline
\end{tabular}

凝固部に存在する等軸晶の粒径の影響を調査するため, 鋳型への注入終了々同時に溶鋼を㩭拌し微細な等軸晶粒

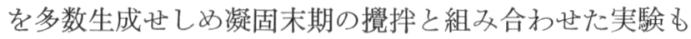

行つた、なお，㩭汼時の溶鋼流速は後述する検討より， $10 \sim 20 \mathrm{~cm} / \mathrm{s}$ と推定された.

\section{3. 実 験 結 果}

\section{1 非䚓拌材のマクロ組織}

Photo. 1 亿非攪拌材の縦断面のマクロ組織を示す. 写真から明らかなように，十分な量の等軸晶が最終凝固 部に生成しても中心部には $\mathrm{V}$ 偏析が生成し軸心部にはポ ロシティが残つている。また，表層から約 $35 \mathrm{~mm}$ の位 置でミク口的に逆 $\mathrm{V}$ 偏析から $\mathrm{V}$ 偏析に変化している。写 真中にはその遷移位置を矢印で示してある。

\section{$3 \cdot 2$ リニア型攪捧コイルによる凝固末期攪找}

Photo. 2 にリニア型コイルを用いて凝固末期の等軸 晶領域を垂直方向に攪拌した場合の代表的な条件に执け るマクロ組織を示す．写真 Cの右側半分のように凝固界 面に上昇流が与兄られると $\mathrm{V}$ 偏析は消滅し, 逆に左側半 分の上らに凝固界面に下降流が与光られると V 偏析は助 長される。また，両側共に上昇流が与兄られた場合の写 真 $\mathrm{B}$ ではV 偏析が消隇している，測温より推定される翼 汼時の固液共存相内の固相率分布を Fig. 2 亿示した. マクロ組織より钼察される偏析線の生成位置, 消滅位置 をこの固相率分布と対比して図中斜線部で示した．凝固 末期垂直上向攪拌に上り固液共存相内の $f_{\mathrm{s}}$ が 0.6 以上 の部分で等軸晶粒間の濃化溶鋼の移動が抑制されている ことが推定される.

以上より凝固界面に上昇流を与光ることが $\mathrm{V}$ 偏析の生

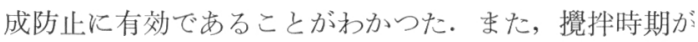
早すぎる条件 $\mathrm{E}$ の場合には V 偏析は残存していることを 実験に上り確認しているので，凝固の末期，鋼塊の軸心 で固相が晶出し始めた直後に㩭拌することが必要である ことがわからた・なお，攪汼時間は本実験の場合には比 較的短時間で十分であった．Fig. 3 には非擳汼材と凝

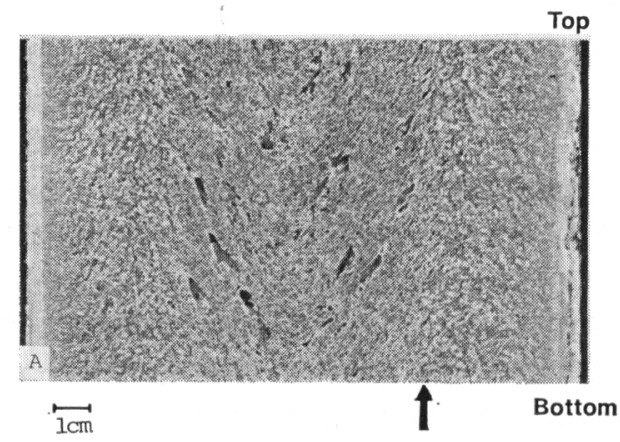

Photo. 1. Macro structure of longitudinal section of ingot without stirring. 

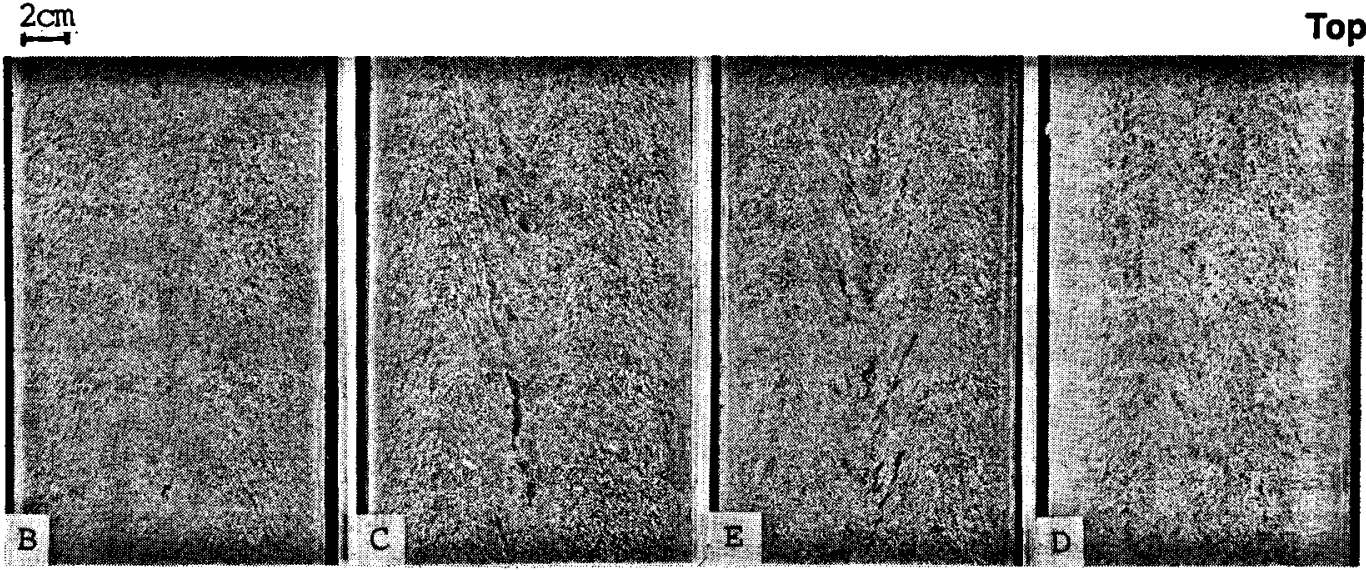

Top

Bottom

Photo. 2. Macro structure of longitudinal section of ingot at various stirring conditions (B, C, E and $\mathrm{D}$ correspond to those shown in Table 3).

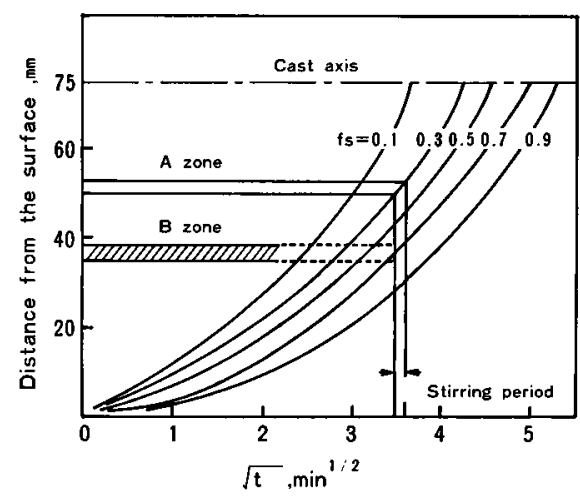

A zone : Progress of solidification front during stirring period, which difined by the fraction of solid equal to 0.3 .

B zone : Segregation streaks located in the zone were control led during stirring period.

Fig. 2. Solid fraction distribution during stirring period.

固末期に $1 \mathrm{~min}$ 連続して上向に挸拌した場合の鋼塊軸 心部の炭素の偏析状況を示した. 分析結果からは, マク 口組織で認められるような明瞙な改善効果は認められな いここれは，本実験においては前述したようにコイル が設置されていない凝固界面には下降流が生じ，この部 分で V 偏析の形成が助長されたためと思われる. 実際 Photo. 2 (B) のマクロ面に垂直な面ではV偏析が助長 されていることを確認している。

したがつて，リニて型膡找ュイルによる垂直方向膡捧 を车操業に応用する場合, 凝固界面の全面にわたつて上 舁流が与えられ，鋳片の軸心においてのみ下降流となる ことが望ましいが，このことは設備的には難しく局所的 に凝固界面に下降流が生ずることは避故られない。この

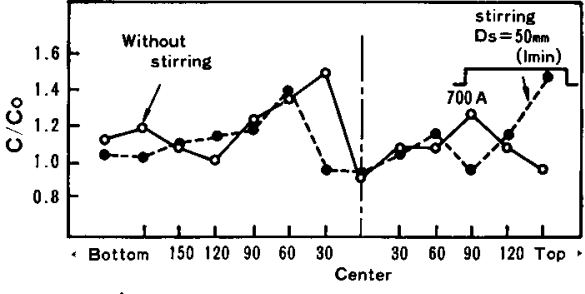

Distance from the center of cast (mm)

Fig. 3. Carbon distributions along center line in the ordinary and the stirred casts.

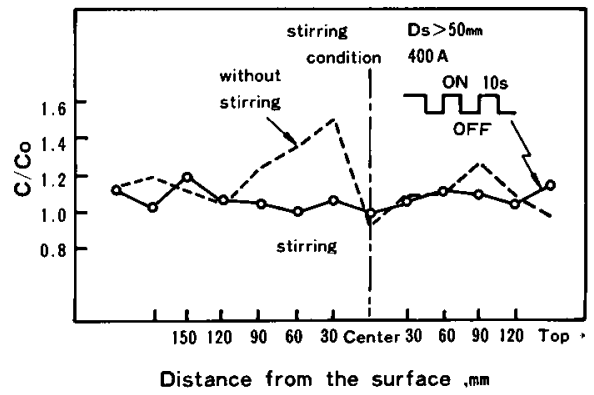

Fig. 4. Garbon distributions along center line in the ordinary and the intermittently stirred casts.

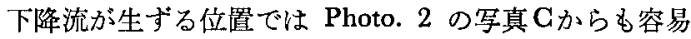
に推定されるようにV偏析が助長される．間けつ弱筧捙 はこの好ましくない下降流を緩和する一つの方法と考党 られる. 凝固末期に $10 \mathrm{~s}$ 間隔で $10 \mathrm{~s}$ ずつ間けつで上 向きに摫拌した場合のマクロ組織を Photo. 2-D に示し た. Fig. 4 にはこの場合の軸心部の偏析状況を非㨘汼 材と比較して示した.このよらな凝固末期間けつ上向熼 


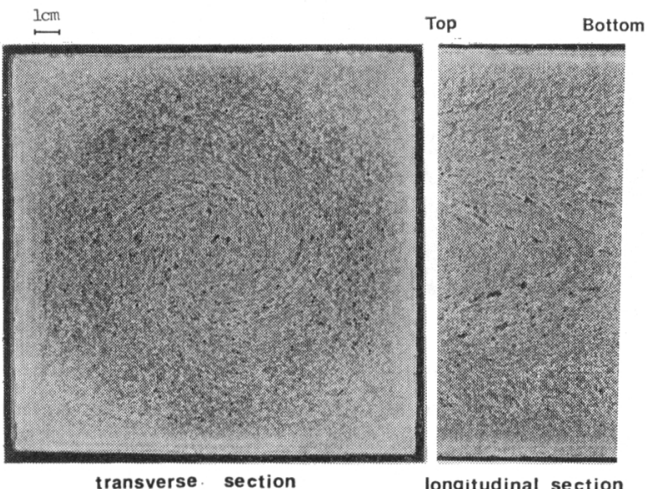

Photo. 3. Macro structure of the transverse and the longitudinal section of ingot with one way rotative stirring.

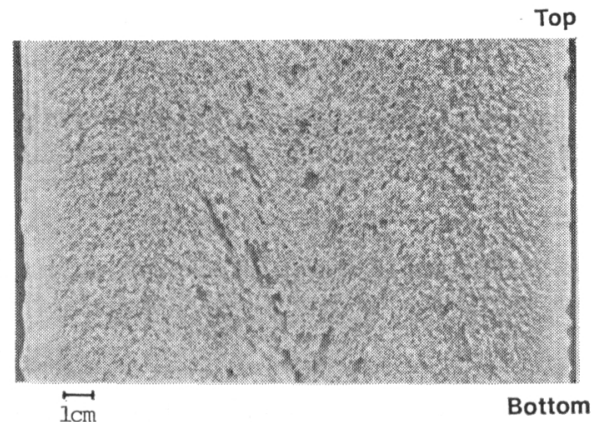

Photo. 4. Macro structure of longitudinal section of ingot with alternating rotative stirring at final stage of solidification.

汼によつてV偏析がなく，かつ軸心上の成分偏析のない 均質な組織が得られることが明らかとなつた。

\section{$3 \cdot 2$ 旋回型攪䢁コイルによる凝固末期攪找}

Photo. 3 には凝固末期の等軸晶領域を水平一方向に 連続して掜找した場合のマクロ組織を示した.コイル設 置位置に和ける横断面では渦巻状の偏析線が，また縌断 面では短い点状の V 偏析線が認められる.すなわちこの 攪汼ではらせん状の濃厚偏析線が攪拌により形成されて いる5 . 前述の Photo. 2 のリニア型攪拌コイルによる 垂直方向相対攪拌の下降流側で偏析線が助長されたと同 樣に，一力向連続の攪拌では，攪拌により偏析線が形成 され内質の改善は達成されない。

Photo. 4 には凝固末期の等軸晶領域を交番攪拌した 時のマクロ組織を示すが若干の効果が認められる程度で ある. 凝固末期の等軸晶領域を攪拌して等軸晶粒の充埧 を達成するためには, 最終凝固部に微細な等軸晶粒を多 数生成せしめることが必要と推定されたため，次に鋳型 への注入終了之同時に溶鋼を攪汼し，凝固末期攪汼を行
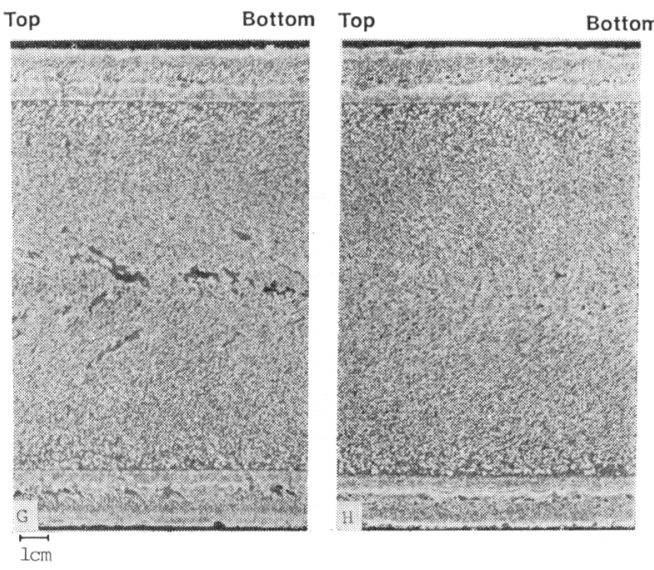

Photo. 5. Macro structures of longitudinal section of ingot with stirring at first stage $(\mathrm{G})$ and stirring at both first stage and final stage $(\mathrm{H})$.

わなからた $(\mathrm{G})$ と, さらに $D_{\mathrm{s}}=50 \mathrm{~mm}$ すなわち鋼 塊の中心で固相が晶出し始める時期に凝固末期攪拌を行 つた $(\mathbf{H})$ のマクロ組織を比較して Photo. 5 に示し た、初期覺拌により微細な等軸晶粒が多数生成したこと が Photo. $1 〜 4$ と比較して明らかである. 微細な等軸 晶を多数生成せしめ, さらに凝固末期に水平方向の交番 攪挥を行らことにより通常認められるV偏析, 中心偏析 は羿められない, 一方, 凝固末期攪拌を行わない $(\mathrm{G})$ ではV偏析が生成して抢り, 中心部にポロシティも残つ ている. Fig. 5，6 には $(\mathrm{H})$ の場合の軸心方向, 半径 方向の成分の偏析状況を非攪拌の場合と比較して示し た. 以上より, 微細な等軸晶粒を多数生成せしめて凝固 末期攪汼を行らと偏析ポロシティのない内質のすぐれた 鋼塊が得られることが明らかとなつた。

Photo. 6 には攪拌時期を $D_{\mathrm{S}}=35 \mathrm{~mm}$ に, すなわち 鋼塊中心部に十分な量の液相が存在する時期に早めた場 合のマクロ組織（I）を $D_{\mathrm{s}}=50 \mathrm{~mm}$ で攪拌した場 合 （J）と比較して示した. 垂直上向き攪拌の場合と同様, 凝固末期攪拌は中心部に十分な量の液相が存在する時期 は不適当である。攪䢁が早すぎると攪䢁終了後にV 偏析 が形成されると推定される。

Photo. 7 には凝固末期攪拌を行つたもの之非覺拌材 の軸心部のミクロ組織を示した. 明らかに微細な等軸晶 を多数生成せしめて凝固末期攪拌を行つた（K）はミク 口偏析が分散して 1 個の偏析粒も小さいが，非攪拌 $(\mathrm{L})$ の方は大きな偏析粒が島状に存在する.この偏析粒のり んの偏析度を XMA により求めて Fig. 7 に示した. 図中には実際のスラブ連鋳に特ける軸心近傍の偏析粒の 大きさと偏析比の関係も同時に示したが，凝固末期攪拝 


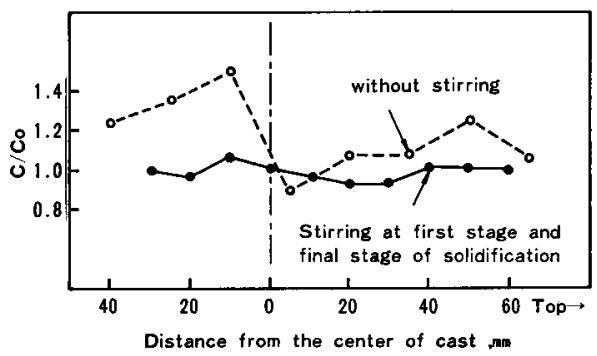

Fig. 5. Carbon distributions along center line in the ordinary and stirred casts.

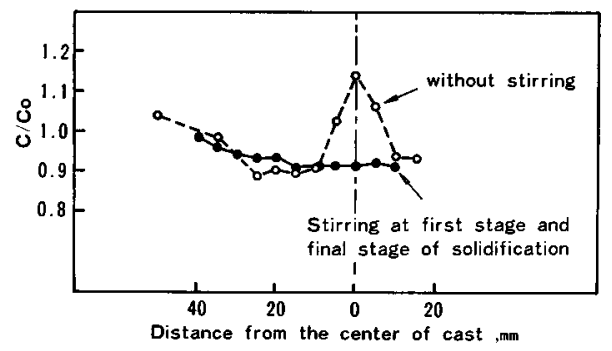

Fig. 6. Garbon distributions along the horizontal direction at the center portion in the ordinary and the stirred casts.

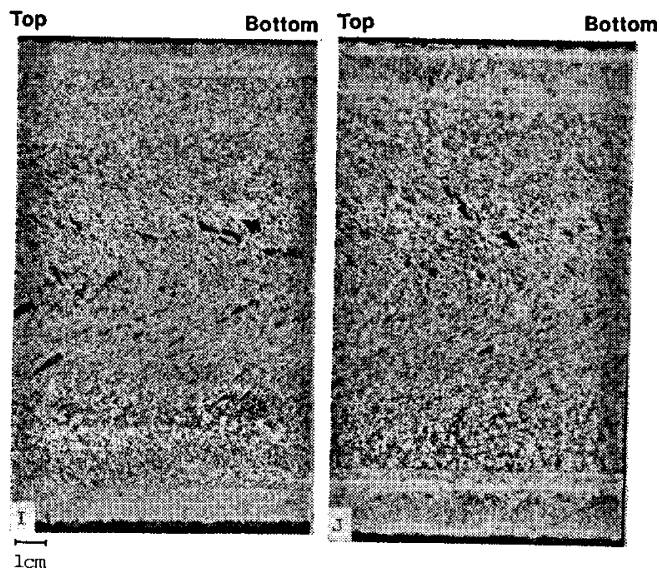

Photo. 6. Macro structures of longitudinal section of ingot with stirring in the earlier period of final stage (I) and stirring in the optimum period $(\mathrm{J})$.

により偏析粒, 偏析比共に小さくなつておりり、クロ的 な分析からも凝固末期擋挥の効果が認められた。

\section{4. 考察}

\subsection{V 偏析の消隇機模}

等軸晶凝固する凝固の最終段階では，凝固の収縮に伴 ら下方への濃化溶鋼の吸引 ${ }^{6) \sim 9}$ によりV偏析の生成は避

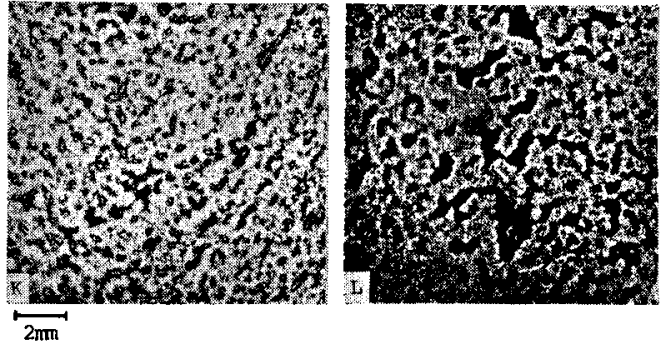

$\mathrm{K}$ : Alternating rotative stirring, $\mathrm{L}$ : without stirring

Photo. 7. Micro structures of ingot in the central zone.

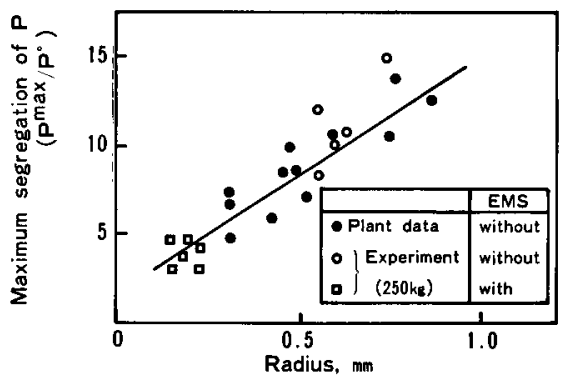

Fig. 7. Relation between particle size and maximum segregation ratio of phosphorus.

けられない，すなわら，凝固の進行に伴う下方への凝固 収縮に追従できなくなつた等軸晶粒（固体）のネットワ 一クのすきを等軸晶粒間の濃化溶鋼（液体）が優先的 に移動するためにV偏析が形成されると考えられる。

FLEMINGS ら ${ }^{10)}$ は凝固の最終段階に打ける固-夜共存 相内の濃化溶鋼の流動に関して詳細な解析を行い, 固一液 共存相内で固体のネットワーク間を濃化溶鋼が鋼塊の内 側へ，すなわち高固相率側から低固相率側へ向かつて下 方へ移動した場合, 局所的に再溶解現象が生じV扁析が 形成されると報告している.

また，浅井ら ${ }^{11}$ は低温模型実験により等軸晶領域にお ける“すべり現象”がV偏析生成のきつかけとなると報 告している。このような“すべり”が起こると固-腋共 存相内の濃化溶鋼はこの“すべり面”に沿つて優先的に 移動するであろう。

以上のことから，V偏析の発生を防止するには以下の 2 通りの方法が考光られる.

1)凝固収縮に追従できなくなつた等軸晶粒(固体)間 を濃化溶鋼（液体）が優先的に移動することを好げる.

2）濃化溶鋼（液体）上等軸晶粒（固体）が凝固の収 樎に追従して同時に移動可能な状態とする.

Fig. 8 にはリニア型穓拌コイルを用いて凝固界面に 垂值方向の撗拌を与克た場合の V 偏析の生成パターンに 


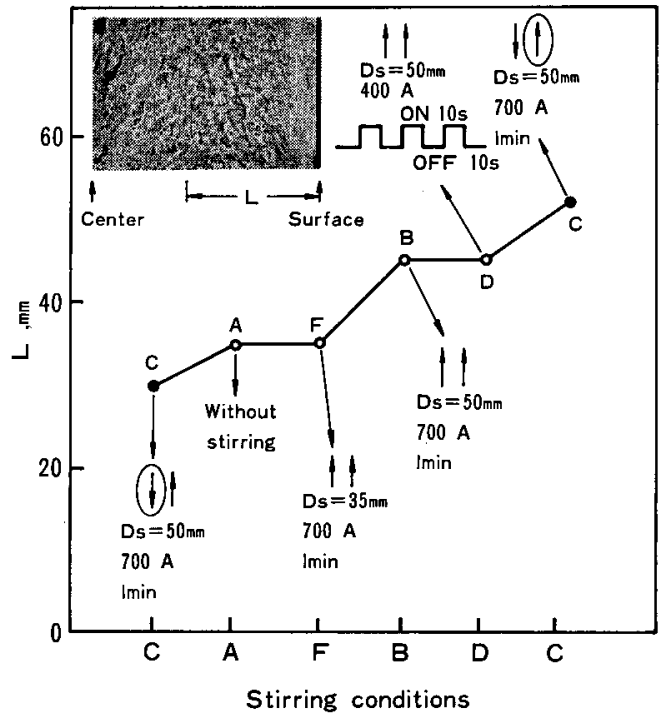

Fig. 8. Effects of stirring conditions on the microscopic V-segregation pattern.

及ぼす筧找方法の影響を示した。濃化溶鋼の下方へのミ クロ的な移動が始まる位置で比較した，図中・，で示し たるのは相対挸汼の下降流側と上昇流側を示している. 図より濃化溶鋼の下方への移動は上向き筧䢁の強度を上 げる注ど凝固の最終段階まで抑制されている。また，逆 に下方への流動を与克た場合には，より早い時期からミ クロ的な流動が起こつている. 以上より，凝固界面の流 動により，固一液共存相内の濃化溶鋼の移動を制御する ことが可能であり, 今回効果のあつた凝固界面の垂直上 向き観挥においては濃化溶鋼の下方への優先移動が妨げ られたためすなわら前述の（1）の理由によりV偏析が 防止されたと考えられる.なお， $D_{\mathrm{s}}=50 \mathrm{~mm}$ で靦找 し た時に表層から約 $35 \mathrm{~mm}$ の位置の粒間の濃化溶鋼の移 動が妨げら犰ており，この位置が摫拌特には固相率が 0.6 以上であると考市られることからV偏析形成開始時 期より早い時期の䚁拌は効果がないと思われる。実際 $D_{\mathrm{s}}=35 \mathrm{~mm}$ で摚拌した場合（F）にはFig. 8 K示した 様にミク口的な濃化溶鋼の流動開始時期は非攂拥の場合 と変わつていない.

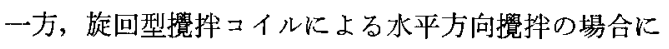
は, 前述した下方への濃化溶鋼の移動開始位置は非擤抖 の場合と変わらない,すなわら, 凝固収縮に伴い固-液 共存相内の濃化溶鋼はミクロ的には非摫拌の場合と同様 に下方へ移動している.この事実之, 最終凝固部の等軸 晶粒径は小さいこと拉よび交番攪汼がV偏析生成防止の 必須条件であることを考劣あわせると，旋回型筧拌コイ
ルによる水平方向の交番攬汼においては等軸晶粒同志の 合体が防止され等軸晶粒の流動性が十分確保されたこと により，等軸晶粒（固体）と粒間の残溶鋼（液体）が凝 固収縮に追従して同時に移動可能な状態となつたため, すなわら前述の（2）の理由によりV偏析の生成が防止さ れたと考它られる。

\section{2 溶鋼流速および最適摠拌時期}

凝固末期攪拌を実操業へ応用する場合，攪拌コイルの パワーの決定は重要な問題である. 本実験に和ける凝固 末期靦捧の溶鋼流速を以下に推定する.

一般に旋回型コイル，リニア型摫挥コイルを用いる場 合, 得られる溶融金属の流速は(1)式で求められる12)13).

$$
\begin{aligned}
& U=K \cdot B \cdot R^{n} \cdot V \bar{f} \cdot \sqrt{\frac{\sigma}{\rho}} \cdot \mu^{-0.44} \\
& \text { ここで } U: \text { 流速 }[\mathrm{cm} / \mathrm{s}] \\
& K: \text { コイルによる決まる定数 } \\
& B \text { : 溶融金属中磁束密度 [Gauss] } \\
& f: \text { 周波数 }[\mathrm{Hz}] \\
& \sigma: \text { 電気伝導度 }[\boldsymbol{\delta} / \mathrm{cm}] \\
& \rho: \text { 密度 }\left[\mathrm{g} / \mathrm{cm}^{3}\right] \\
& \mu: \text { 粘性 [c.p.] }
\end{aligned}
$$

(1)式中のRは旋回摫找の場合にはバルク半径であり $n$

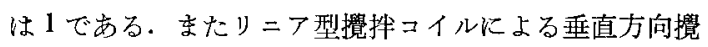
拌の場合のRはバルクの幅であり, $\mathrm{n}$ は $\mathrm{N}-\mathrm{N}$ 対向の対 称型攪拌扎よび相対型覺拌において 0.5 である.本実 験で用いた摫捧コイルについて $(1)$ 式の定数 $K$ を水銀モ デル実験で求め，凝固末期の未凝固溶鋼（等軸晶粒+残 溶鋼）の平均的な粘性 $(\mu)$ を涉谷ら ${ }^{14)}$ の测定結果より 推定して溶鋼流速を計算すると, 旋回型摫拌については $U=20 \mathrm{~cm} / \mathrm{s}$ となる. 交番攪拌では溶鋼の起動時間を考 慮するとさらに小さくなる・一方りニア型覞拌について は $10 \sim 15 \mathrm{~cm} / \mathrm{s}$ 程度の流速となつた.

䚇拌コイルのパローの決定とともに, 攪拌ュイルの設 置位置を決定することも重要である. 本実験から, 中心 部に十分な量の液相が存在する時期は早すぎ, 軸心部で 固相が晶出し始める時期が適当であることが推定され た.

実操業に扣いては，鋳造方向の 固-液共存相が長いと か，凝固収縮量が本実験とは異なるなど未知の部分が多 いが，今回得られた摫挥推力抋よび最適攪抖時期に関す る知見は実操業への応用に際しての有益な基儊データで ある。

\section{5. 結 論}

連鋳々片の内質の向上の目的で，最終凝固部の等軸晶 
領域を䚌拌する電磁挸拌方法について実験室的検討を行 い以下のことがわかつた。

(1) 等軸晶凝固する最終㠜固部の凝固界面に上昇流 を与兄ることにより固液共存相内の濃化溶鋼の下方への 優先移動を妨げ，V 偏析，中心偏析，ポロシティのない 内質の優れた鋼塊が得られる.

(2) 最終凝固部に微細な等軸晶粒を多数生成 せ 乙 め，さらに水平方向の交番穓找を与えることにより等軸 晶粒同志の合体を防ぎ, 流動性が確保され, その結果 V 偏析，中心偏析，ポロシティのない内質の優れた鋼塊が 得られる。

（3）凝固末期の必要攪汼推力は，流速換 算で 10 $20 \mathrm{~cm} / \mathrm{s}$ の弱い攪挥で十分と推定された.

（4）最適攪拌時期は鋼塊の軸心部で固相が晶出し始 める時期と推定された.

\section{交献}

1）川上公成, 細田義郎, 伊藤雅治：学振 19 委-No. 9629 (昭和 48 年 9 月)
$2) \quad R$. Alberny, $L$. Angel, $J$. P. Birat, $J$. Chone, $R$. Goetzinger, $E$. Grethen, and $N$. Kaell: International Iron and Steel Congress, Chicago (1978) Apr.

3 ) 岩田 斉, 山田勝彦, 藤田照夫, 林 享三：鉄と 鋼, 61 (1975), p. 2972

4）森隆資，綾田研三：神戸製鋼技報, 29 (1978) 3, p. 16

5 ）山田勝彦，多田英昭，藤田照夫：鉄と鋼， 65 (1979), S 700

6 ) Report on Heterogeneity of Steel Ingots: JISI, 113 (1926), p. 39

7 ) 蒔田宗次：鉄と鋼，13 (1927), p. 1001

8 ) A. Hultgren: JISI, 120 (1929), p. 69

9) 鈴木是明, 宮本剛沉：鉄と鋼，59 (1973), p. 431

10) M. $C$. Flemings and $R$. Mehrabian: ASM Seminar on Solidification, Philadelphia (1969) Oct.

11）井上 肇，浅井滋生，鞭 筑：鉄と鋼， 67 (1981), S 260

12）水上秀昭，小松政美，川上公成：鉄と鋼, 66 (1980), S 800

13）水上秀昭, 小松政美, 北川 融, 川上公成：鉄と 鋼, 68 (1982), S 254

14）渋谷明彦，有原和彦，中村 泰：鉄と鋼, 66 (1980), p. 1550 